УДК 342.2(438)

DOI https://doi.org/10.32837/pyuv.v1i3(28).318

\author{
M.I. Марчук \\ кандидат юридичних наук, доцент, \\ завідувач кафедри конституційного і міжнародного права \\ факультету № 4 \\ Харківського національного університету внутрішніх справ
}

\title{
ТЕРИТОРІАЛЬНЕ САМОВРЯДУВАННЯ РЕСПУБЛІКИ ПОЛЬЩА ЯК СКЛАДНИК ЄВРОПЕЙСЬКОЇ РЕГІОНАЛЬНОЇ СТРАТЕГІЇ
}

Відновлення в 1990 р. у Польщі територіального самоврядування базувалося на досвідові міжвоєнних традицій. Водночас з переходом Польщі до побудови капіталістичних відносин поступово виникла потреба в оптимізації її самоврядних структур із врахуванням особливостей діяльності місцевих органів влади в Західній Європі. Доказом цього стали основні структурні реформи 1998 р., пов'язані із запровадженням нового основного територіального поділу, який складався з трьох щаблів - гміни, повяту й воєводства - і повинен був відповідати принципу, за яким кожна одиниця поділу повинна бути одночасно одиницею місцевого самоврядування з відповідним обсягом повноважень [1, с. 179].

Варто наголосити на тому, що польське самоврядування після реформ 1998 року набуло нового виміру та певної сталої форми. Проте було б помилкою ставитися до територіального (місцевого) самоврядування Республіки Польща як до статичної структури, навпаки, ця самоврядна владна підсистема перебуває в постійному розвитку. Підтвердженням цього є подальші значні зміни в структурі та принципах місцевого самоврядування на всіх рівнях, внесені Законом від 11.04.2001 р. "Про зміну законів про самоврядування у гміні, про самоврядування у повіті та самоврядування у воєводстві, про урядову адміністрацію у воєводстві та зміну деяких інших законів» [2], а також Законом від 20.06.2002 p. «Про прямі вибори війта, бургомістра і мера» [3], що стали результатами наближення територіальних структур Польщі до європейських самоврядних стандартів. Саме за умов, коли зовнішня політика України спрямована на євроінтеграцію, існує нагальна потреба вивчення еволюції національних самоврядних структур у контексті європейських інтеграційних процесів. Це зумовлює актуальність даної теми дослідження.

Проблемам територіального самоврядування Республіки Польща приділяло увагу чимало науковців, зокрема В. Зайонц [4], Х. Іздебські [5], М. Лендьєл [6], В. Малиновський [7], Є. Регульскі [8] та ін.

Загалом публічна адміністрація Республіки Польща порівняно добре досліджена у спільних наукових працях польських (Я. Гонцяж, З. До- лецький, Л. Колярсько-Бобинська М. Кулеша) та українських (Н. Гнидюк, О. Куленкова, В. Гуменюк) учених, хоча особливості еволюції самоврядних інституцій Республіки Польща у контексті євроінтеграційних процесів висвітлені досить слабко [9].

Мета статті полягає у з'ясуванні особливостей впливу євроінтеграційних процесів на систему місцевого (територіального) самоврядування Республіки Польща.

Політичні перетворення в Польщі після 1989 р. вплинули на всю систему публічної влади Республіки Польща та її суб'єктів. Її подальша еволюція в напрямі створення громадянського суспільства стимулювала перехід від авторитарної держави до демократичної та правої. Були створені відповідні правові і політичні механізми для розвитку й функціонування політичної системи. Адміністративна реформа призвела до передачі компетенції від урядової адміністрації до новостворених регіонів. Дворівневий поділ територіальних органів влади був замінений на трирівневий (гміна, повіт, воєводство). Водночас у цей період у таких країнах $Є C$, як Іспанія, Німеччина і Великобританія, кількість рівнів місцевого самоврядування не тільки не збільшилася, а й почала скорочуватися [10].

Членство в Європейському Союзі робить необхідною адаптацію державного управління держав-членів до процедур прийняття рішень у ЄС та їх відповідності спільним стандартам у цій галузі. Для цього Польща повинна була пройти певний процес європеїзації з таких питань, як демократична легітимність управління, нормативне визначення правил і обмежень самоврядної діяльності, контроль за доцільністю і законністю дій тощо. Суть даного процесу полягала у поступовому включенні трирівневої системи територіального самоврядування Республіки Польща в процес європейської інтеграції та структурного прийняття рішень [11, с. 46-62].

Важливу роль у цьому процесі повинна була відіграти доктрина субсидіарності держави, децентралізації та деконцентрації влади, а також участь місцевого самоврядування у здійсненні публічної влади [12]. Варто відзначити той факт, що у рамках територіальної (локальної) політики ЄС 
саме регіони є основною ланкою реалізації самоврядних функцій і одержувачами коштів зі структурних фондів для вирівнювання диспропорцій i якості життя їх мешканців.

Для отримання і ефективного використання коштів ЄС у різних регіональних програмах від регіонів вимагається ефективне програмування, фінансування і моніторинг з боку органів місцевого самоврядування. 3 цією метою Європейський Союз надає відповідну допомогу країні-кандидату на вступ до ЄС як до приєднання, так і після нього для підготовки органів самоврядування до належної співпраці зі структурними фондами ЄС.

Регіональна політика в державах-членах ЄC координується відповідними міністрами урядів. Загрозою для її належної реалізації можуть бути помилки в координації, відсутність належним чином підготовленого персоналу чиновників, їх відповідальності тощо. Це може призвести до виникнення різних порушень та аномалій у сфері належного використання коштів ЄС в окремих галузях. Існують також значні відмінності між управлінням коштами, наданими країні-кандидатові перед вступом до ЄС, та структурними коштами після досягнення членства у ЄС. Це стосується як розміру виділених фондів ЄС, так і принципів, стандартів та критеріїв їх використання країнами-бенефіціарами.

Необхідно зазначити, що Польща вступила в ЄС у 2004 р. в якості третьої з кінця найбіднішої країни, обігнавши за темпами економіки лише Литву та Латвію. Проте у період до 2008 року ці країни обігнали Польщу за показниками приросту ВВП на людину, і уже тільки новоприйняті у 2007 р. до ЄС Болгарія та Румунія відставали від Польщі за економічними показниками. Низький рівень ВВП у Польщі тих років був наслідком не тільки слабкого розвитку польської економіки, але й найнижчого у ЄС рівня зайнятості (у 2006 році лише 52\% поляків віком від 15 до 64 років були працевлаштованими, для порівняння в середньому у ЄС - $63 \%$, а у країнах Скандинавї - 70-80\%).

Однак вступ Польщі до ЄС все ж таки призвів до значного зростання національної економіки. Так, у 2004-2007 pp. приріст ВВП Польщі $(5,4 \%$ ) був у 2 рази вищий, ніж у 2000-2003 роках $(2,7 \%)$. Це, зокрема, стало результатом включення польської економіки до загальноєвропейського ринку, прямого притоку іноземних інвестицій та збільшення торгового обігу з країнами ЄС.

У період 2007-2013 рр. Польща стає найбільшим бенефіціаром європейської політики згуртованості. Загалом від моменту вступу до СС вона отримала майже 85,3 млрд євро. Щоправда, як член ЄС країна також здійснює внески до бюджету Союзу, тому сукупний обсяг трансфертів нетто дещо менший - 65 млрд євро. У рамках політики вирів- нювання було отримано 52,8 млрд євро, а в рамках спільної сільськогосподарської політики - ще 28,2 млрд. Лише у 2012 р. з бюджету ЄС Польща отримала майже 12 млрд євро «чистими». У бюджеті ЄC на 2014-2020 рр. Польщі було призначено 105,8 млрд євро (з них 72,9 млрд - у рамках політики вирівнювання) [13].

Вказаний об'єм вкладених коштів свідчить, що Польща отримує найбільший за всю історію ЄC пакет допомоги. 3 огляду на значну економічну диференціацію польських воєводств при розподілі коштів братиметься до уваги стан речей у кожному із них. Кошти виділятимуться тим регіонам, які перебувають у найменш сприятливому становищі.

Європейський Союз заснований на принципі взаємності та солідарності держав, що вирішили спільно боротися 3 глобальною конкуренцією i працювати разом для соціального й економічного розвитку. Для цього ЄС потребує нової регіональної політики, адаптованої як до вимог самого Союзу, так і до постійних змін, які характеризують сучасний світ.

У результаті послідовного розширення ЄС включає вже понад 260 регіонів - лендів, департаментів, провінцій тощо, створюючи Європу регіонів. Регіони де-факто стають новим виміром європейської інтеграції, що враховує самоврядність більш низьких рівнів політичної автономії та наближує процес прийняття рішень до громадян. Як зазначає проф. 3. Бродєцькі, «<...> регіони $є$ основною одиницею політичного, адміністративного, економічного, соціально-культурного і національного об'єднання Європи» [14, с. 22].

У сучасній Європі саме на регіони покладається завдання щодо вирішення проблем, пов'язаних 3 економічною глобалізацією, демографічними тенденціями, зміною клімату, енергопостачанням або безпрецедентними загрозами безпеці. Проте окремі регіони не в змозі вирішити усі ці питання самостійно. Вирішенням цієї проблеми можуть бути спільні зусилля на європейському рівні. 3 огляду на це цілком логічним було реформування правил, закріплених у договорах про співіснування в рамках ЄC [15, с. 23-31]. Саме таке завдання покладалося на новий договір про ЄС, який був підписаний 13.12 .2007 р. в Лісабоні і набув чинності 01.12.2009 р. [16, с. 7-38]. Лісабонський договір вніс зміни в установчі договори ЄС, не замінюючи їх. При цьому він озброїв Євросоюз правовими інструментами, необхідними для задоволення потреб і очікувань суспільства на місцевому рівні [17, с. 253].

Про ту значну роль, яку відіграє місцеве самоврядування для реалізації стратегії, передбаченої Лісабонським договором, свідчить і заклик обраної на термін з 2010 до 2012 р. Президентки Комітету регіонів М. Брессо, яка вказала не не- 
обхідність вдосконалення європейської політики єднання через посилення відповідальності держав-членів за подальші інтеграційні процеси та звернула увагу на необхідність врахування інтересів місцевих і регіональних громад, оскільки саме вони стоять на лінії антикризового фронту і є peальними лабораторіями інновацій в економічній, соціальній та екологічній сферах [18].

Для реалізації цієї стратегії був розроблений план спільних дій країн-членів ЄС, який отримав назву «ЄC 2020» і мав дозволити ЄC повністю вийти із кризи і прискорити перехід до інтелектуальної й екологічно чистої економіки.

В основу Стратегії «ЄС 2020» покладається політика територіальної згуртованості. По-новому трактується роль регіонів у цьому процесі. Вона розуміється як діяльність регіонів та держави в рамках політики згуртування, із одночасним підпорядкуванням пріоритетам спільної стратегії. При цьому в означених відносинах саме на центральний уряд покладається роль просування регіонального розвитку, а його діяльність повинна враховувати усі базові вектори національного розвитку, які повинні бути географічно орієнтованими і слугувати доповненням до діяльності, здійснюваної керівництвом регіонів. Водночас одним $з$ пріоритетів державної регіональної політики повинен стати розвиток промислових регіонів, у такий спосіб підтримуючи створення належних умов для їхнього динамічного розвитку.

Отже, посилення політики згуртованості, заснованої на знаннях та інноваціях у енергозберігаючих галузях економіки, дозволить підтримувати економічні, соціальні та територіальні засоби згуртованості на належному рівні і допоможе сконцентруватися не на самому вирівнюванні диспропорцій між регіонами, а на усуненні факторів, що зумовлюють таку нерівність, - слабкої освітньої кваліфікації, відсутності інноваційних проєктів, недостатнього забезпечення підприємств зеленими технологіями тощо.

Важливим фактором польської регіоналізації стала політика економічної і соціальної єдності усієї держави. Це дозволило запобігти маргіналізації у проблемних зонах. Важливим елементом реформування регіональної політики стало й підвищення ефективності управління, налаштованість на результат, а не лише на дотримання процедур. Умовою успішної реалізації такого підходу повинна була стати не лише децентралізація владних функцій, але й зменшення кількості самих правил і бюрократичних процедур, перехід до політики партнерства між інститутами держави та регіональної влади.

Недоліком включення місцевого (територіального) самоврядування Республіки Польща до євроінтеграційного процесу можна вважати те, що реформування фінансової системи Польщі майже не дозволило провести децентралізацію державних коштів для збільшення доходів на місцях. Можливо, реформа також мала на меті зменшення дефіциту бюджету за рахунок перекладення вирішення цього питання на плечі органів місцевого самоврядування. Це мало наслідком те, що воєводства й досі позбавлені достатніх ресурсів для втілення інвестиційних проєктів, що зменшує здатність проводити регіональну політику [19, с. 281]. Також важливими організаційними проблемами для польського уряду стали структурні питання регіональноїполітики таїкоординації.

Підсумовуючи, констатуємо, що польська система регіонального розвитку натепер недостатньо дозволяє реалізовувати національні та регіональні стратегії розвитку, оскільки вона надмірно зосереджена на освоєнні європейських коштів та на виконанні вказівок і рекомендацій Свропейського Союзу. Така слабкість польської регіональної політики може створювати труднощі у визначенні інших національних і регіональних пріоритетів у сфері розвитку.

Вважаємо, що для ефективної реалізації регіональної політики польським посадовцям доцільно першочергово зробити повну реконструкцію системи державних фінансів у такий спосіб, щоб центральна та місцева влада отримала власні кошти і інвестиційні фонди, адже дотація з боку ЄС закінчиться у 2020 р. Саме тому потрібні чіткі й системні дії, підкріплені інституційними та нормативно-правовими основами, не лише для отримання фінансової допомоги з СС, але й для розвитку власної регіональної політики [20].

Також зауважимо, що регіоналізація i децентралізація є важливими передумовами економічної конкуренції між окремими населеними пунктами і регіонами. Така конкуренція в українських реаліях могла б стати оптимальною базою для подальшого економічного розвитку держави, могла б зміцнити її позиції в умовах міжнародної конкуренції.

Варто зазначити, що саме дослідження небажаних факторів впливу на регіональні інституції країн-членів Євросоюзу є перспективними напрямами подальших наукових досліджень у самоврядній площині.

\section{Jimepamypa}

1. Байрак С.О. Еволюція місцевого самоврядування Республіки Польща у процесі демократичної трансформації. Панорама політологічних студій. 2012. Вип. 8. C. 174-181.

2. Ustawa z dnia 11 kwietnia 2001 r. o zmianie ustaw : o samorządzie gminnym, o samorządzie powiatowym, o samo rządzie województwa, o administracji rządowej w województwie oraz o zmianie niektórych innych ustaw. $D z$. $U$. 2001 r. Nr 45, poz. 497.

3. Ustawa z dnia 20 czerwca 2002 r. o bezpośrednim wyborze wójta, burmistrza i prezydenta miasta. $D z$. $U$. 2002 r. Nr 113, poz. 984. 
4. Zajac W. Zasadniczy trojstopniowy podzial terytorialny Polski. Warszawa, 1999. $227 \mathrm{~s}$.

5. Izdebski H. Samorzad terytorialny. Podstawy ustroju i dzialnosci. Warszawa : Wydawnictwo Prawnicze. LexisNexis. 2006. $314 \mathrm{~s}$.

6. Лендьєл М. Місцева демократія у країнах Центральної та Східної Європи. Ужгород : Мистецька лінія, 2011. 688 c.

7. Малиновський В. Реформування територіальної організації влади Польщі: уроки для України. Вісник НАДУ. 2007. № 3. С. 235-243.

8. Regulski J. Samorzad III Rzeczypospolitej. Koncepcje i realiyacja. Warszawa : PWN, 2000. $214 \mathrm{~s}$.

9. Гонцяж Я., Гнидюк Н., Куленкова О., Гуменюк В. Самоврядування та територіальна організація в Польщі / за заг. ред. Я. Гонцяжа. Київ : Міленіум ; Вид-во УАДУ, 2001. 184 с.

10. Wilczak D. Samo się nie rządzi. Newsweek. 2010, 14 Marca.

11. Szyjko C. T. Scenariusze rozwoju polityki spójności w UE po 2006 r. Commentationes. Zeszyt Naukowy WSM. 2005. Nr. 2(1). S. 446-62.

12. Administracja i polityka. Europejska administracja publiczna // red. R. Wiszniowski. Wrocław : Wydawnictwo Uniwersytetu Wroclawskiego, 2005. $150 \mathrm{~s}$.

13. Інтеграція до СС : досвід Польщі та виклики для України. Дзеркало тижня. Україна. 2013. № 35. 27 верес. - 4 жовт. URL: https://dt.ua/macrolevel/ integraciya-do-yes-dosvid-polschi-ta-vikliki-dlya-ukrayini- html.

14. Brodecki Z. Prawo europejskiej integracji. Warszawa : Wydawnictwa Prawnicze PWN, 2000.215 s.

15. Prawo europejskie / F. Emmert, M. Morawiecki. Wyd. 3 zm. Warszawa ; Wrocław : Wydaw. Naukowe PWN, 2002.607 s.

16. Szyjko C. T. Traktat z Lizbony - geneza, uwarunkowania, proces implementacji [w:] Droga Polski do Lizbony. Piotrkowskie Studia Międzynarodowe. 2009. Nr 1.7-38.

17. Davies N. Europa między Wschodem a Zachodem, przeł. B. Pietrzyk, Kraków : Wyd. Znak. 2007. 351 s.

18. Stenograma posiedzenia zamieszczonego na oficjalnej stronie Komitetu : http://www.cor.europa.eu/ pages/PresentationTemplate.aspx ?view=detail\&id= cdd1e5b8-1848-4a95-8e1fa0999c9ae7a.

19. Савка О. В. Регіональна політика Польщі уроки для України. Вісник Маріупольського державного університету. Серія : Історія. Політологія. 2015. Вип. 12. С. 277-283.

20. Gądecki J. Osiedla grodzone w Polsce - analiza dyskursu. Wrocław : Uniwersytet Wrocławski, 2009. $300 \mathrm{~s}$.

\section{Анотація}

Марчук М. I. Територіальне самоврядування Республіки Польща як складник європейської регіональної стратегії. - Стаття.

Мета статті полягає у з'ясуванні особливостей впливу євроінтеграційних процесів на систему місцевого (територіального) самоврядування Республіки Польща. 3 переходом Польщі до побудови капіталістичних відносин поступово виникла потреба в оптимізації її самоврядних структур із врахуванням особливостей діяльності місцевих органів влади в Західній Свропі. У статті досліджено основні напрями демократизаціі локальних самоврядних інституцій Польської Республіки та новітні досягнення європейської регіональної стратегії. Виокремлено основні негативні фактори, що мають суттєвий вплив на економічні, соціальні та територіальні засоби згуртованості. 3'ясовано, що поль- ська система регіонального розвитку нині недостатньо дозволяє реалізовувати національні та регіональні стратегії розвитку, оскільки вона надмірно зосереджена на освоєнні європейських коштів та на виконанні вказівок і рекомендацій Європейського Союзу. Така слабкість польської регіональної політики може створювати труднощі у визначенні інших національних і регіональних пріоритетів у сфері розвитку. Визначено, що для ефективної реалізації регіональної політики польським посадовцям доцільно першочергово зробити повну реконструкцію системи державних фінансів у такий спосіб, щоб центральна та місцева влада отримала власні кошти й інвестиційні фонди, адже дотація з боку ЄС закінчиться у 2020 р. Недоліком включення місцевого (територіального) самоврядування Республіки Польща до євроінтеграційного процесу є те, що реформування фінансової системи Польщі майже не дозволило провести децентралізацію державних коштів для збільшення доходів на місцях. Наголошено, що регіоналізація і децентралізація є важливими передумовами економічної конкуренції між окремими населеними пунктами і регіонами. Така конкуренція в українських реаліях могла б стати оптимальною базою для подальшого економічного розвитку держави та зміцнити її позиції в умовах міжнародної конкуренції. На підставі з'ясованих особливостей зроблено висновок про те, що не вирівнювання диспропорцій між регіонами є основою для політики регіональної єдності, а саме усунення факторів, що зумовлюють таку нерівність.

Ключові слова: інтеграція, територіальне самоврядування, територіальна згуртованість, регіональна єдність, субсидіарність, децентралізація, деконцентрація.

\section{Summary}

Marchuk M. I. Territorial self-government of the Republic of Poland as a component of European regional strategy. - Article.

The purpose of the article is to find out the peculiarities of the influence of European integration processes on the system of local (territorial) self-government of the Republic of Poland. With the transition of Poland to the construction of capitalist relations, there is gradually a need to optimize its self-governing structures, taking into account the peculiarities of the activities of local authorities in Western Europe. The territorial self-governance of the Republic of Poland as a component of the European regional strategy. The basic direction of democratization of local self-governing institutions of the Republic of Poland and the latest achievements of European regional strategy are investigated. The basic negative factors have a significant impact on economic, social and territorial cohesion funds. It has been found that the Polish system of regional development is currently not sufficiently capable of implementing national and regional development strategies, as it is overly focused on the "development" of European funds and on the implementation of EU guidelines and recommendations. The perceived weakness of Polish regional policy may make it difficult to identify other national and regional development priorities. It is determined that in order to effectively implement regional policy, it is advisable for Polish officials to make a complete overhaul of the public finance system so that central and local authorities receive their own funds and investment funds, especially since the EU subsidy will end in 2020. The disadvantage of involving the local (territorial) self-government of the Republic of Poland in the European integration process is the fact that the reform of the financial system of Poland has not fully enough allowed to 
carry out the decentralization of public funds to increase local income. It is emphasized that regionalization and decentralization are important prerequisites for economic competition between individual settlements and regions. And such competition in the Ukrainian realities could become an optimal basis for further economic development of the country and strengthen its position in international competition. Based on the ascertained characteristics, it is concluded that not leveling disparities between regions is the basis for the policy of regional unity, namely, the elimination of factors contributing to these inequalities.

Key words: integration, territorial self-government, territorial cohesion, regional unity, subsidiarity, decentralization, deconcentration. 